\title{
Characterization of the surface water of a municipal natural park by quality indexes
}

\author{
Thayna Suane Pollhein ${ }^{\mathrm{a}}$, Josiane Teresinha Cardoso ${ }^{* a}$, Viviane Aparecida Spinelli Schein ${ }^{\mathrm{b}}$ \\ a Laboratório de Toxicologia Ambiental, Universidade do Estado de Santa Catarina, Lages, CEP 88520-000, Santa Catarina, Brazil. \\ *josiane.cardoso@udesc.br \\ b Laboratório de Físico-Química, Universidade do Estado de Santa Catarina, Lages, CEP 88520-000, Santa Catarina, Brazil.
}

Received: April 2, 2019 / Accepted: May 5, 2019 / Published online: May 27, 2019

\begin{abstract}
Conservation units are important for maintaining environmental resources. In this study, the water quality of the Lages Natural Park was evaluated by commonly used indexes: WQI, BMWP' and Shannon Diversity. Water and sediments were collected at seven points inside the CU and at one point outside it. For the evaluation of the WQI, nine parameters were measured: dissolved oxygen and temperature at the site, and the others at the laboratory. For the calculation of the BMWP' and Diversity indexes, the benthic macroinvertebrates in the sediment were identified. The BMWP' and Shannon indexes indicate a worse quality of the waters at the points $1,2,6,7$ and 8 (contaminated water and less diversity) than the WQI (quality ranging from good to optimal). The points 3, 4 and 5 had little polluted water according to BMWP' and optimal according to WQI. The results show the contamination of the water inside the park. There is a need for an investigation of its surroundings to determine the sources of contamination. It was also possible to prove the influence the riparian forest exerts in preserving the quality of the water. The difference in the sensitivity of the indexes proves the need to use biological analysis in water monitoring systems.
\end{abstract}

Keywords: Benthic macroinvertebrates, WQI, BMWP', water quality.

\section{Caracterização das águas superficiais de um parque natural municipal por meio de índices de qualidade}

\begin{abstract}
Resumo
As unidades de conservação são importantes para manutenção dos recursos ambientais. Nesse estudo avaliou-se a qualidade da água do Parque Natural de Lages, através de índices comumente utilizados: IQA, BMWP' e Diversidade de Shannon. Coletouse água e sedimentos em 7 pontos dentro da UC e um fora. Para avaliação do IQA mediu-se nove parâmetros, sendo o oxigênio dissolvido e temperatura no local, e os demais em laboratório. Para o cálculo dos índices BMWP' e de Diversidade fez-se a identificação dos macroinvertebrados bentônicos presentes no sedimento. Os índices BMWP' e Shannon indicaram pior qualidade das águas dos pontos 1, 2, 6, 7 e 8 (águas contaminadas e com menor diversidade) que o IQA (qualidade variando de boa a ótima), os pontos 3, 4 e 5, mostraram-se com águas pouco poluídas pelo BMWP' e ótimas pelo IQA. Os resultados mostram a contaminação das águas no interior do parque havendo necessidade de uma investigação do seu entorno para averiguar as fontes de contaminação. Também se pôde comprovar a influência que a mata ciliar tem para preservação da qualidade da água. A diferença na sensibilidade dos índices utilizados evidencia a necessidade de se introduzir a análise biológica nos sistemas de monitoramento das águas.
\end{abstract}

Palavras-chave: Macroinvertebrados bentônicos, IQA, BMWP', qualidade da água.

\section{Introduction}

Conservation units (CU) are territorial spaces delimited with the purpose of ensuring the representativeness of significant and ecologically viable samples of different populations, habitats and ecosystems of the national territory and jurisdictional waters, preserving the existing biological heritage (MMA, 2018).

The importance of scientific-environmental research in conservation units is given by the need to evaluate whether the objective of such units is being fulfilled. With this purpose, surveys can be carried out to evaluate water quality in rivers inside CUs. For Matthiensen (2014a), the survey consists of the collection of short-term data with a finite duration, usually less than a year, more intensively to observe and measure the quality of an aquatic environment for a specific purpose.

Indexes provide an overview of water quality as they integrate the results of several variables into a single indicator (CETESB, 2015). Currently, the water quality of the rivers is 
determined in several countries by using the WQI index. It is a mathematical relation that transforms several analyses of physical-chemical parameters of the water into a single number (Maane-Messai, Laignel, Motelay-Massei, Madani \& Chibane, 2010).

The sediment has also been increasingly used in quality assessment studies of aquatic ecosystems because it reflects historical conditions of influences of anthropic activities on these environments, which are not always detectable by using water variables (CETESB, 2015). Among the factors that reflect sediment quality, the benthic community stands out. The benthic community comprises organisms that inhabit the bottom of these environments during the whole or part of their life cycle. They are associated to the most diverse types of substrates, both organic and inorganic (Taniwaki \& Smith, 2011) and commonly used as bioindicators of quality of lotic environments.

Communities have been used for the calculation of biotic indexes of water quality. The Biological Monitoring Work Party System (BMWP), developed for the rivers of England (BMWP index), is one of the most popular indexes. In Brazil, the most applied version has been the BMWP' index adapted by Alba-Tercedor and Sánchez-Ortega (1988) for the Iberian Peninsula and modified for the Paraná rivers by the Environment Secretariat of Paraná (SEMA/PR) (2018).

In order to contribute to the environmental management of the Lages Municipal Natural Park and assist in the elaboration of the new management plan, this study has as main objective to evaluate the water quality of the Lages Municipal Natural Park, SC, by using the water quality index (WQI), the BMWP' biological index, and ecological parameters such as the Shannon Diversity index.

\section{Material and Methods}

\section{Characterization of the study area}

The João José Theodoro da Costa Neto Municipal Natural Park, located in Lages, SC, is an integral protection conservation unit. It has 2.3 million square meters. Part of the area is a full protection area, and part is open to visitors (City Hall of Lages, 2006). Within the park, there are springs that debauch in the Passo Fundo River, which, in turn, is a tributary of the Carahá River, which belongs to the Canoas River Basin and cuts off part of the urban area of Lages. The area is located in a higher area of the park near the intersection of the BR-116 and BR-282e roads. There are industries and housing very close to the unit.

For the collections, eight points were selected and marked with a GPS Garmin 62sc (Figure 1): seven points were inside the park and one point was outside the area. This was done in order to evaluate the degree of contamination of the river immediately after its exit under the influence of houses in its surroundings.

The point $1\left(27^{\circ} 47^{\prime} 36.65^{\prime \prime} \mathrm{S}, 50^{\circ} 20^{\prime} 49.65^{\prime \prime} \mathrm{W}\right)$ had running water and preserved riparian vegetation; the point 2 $\left(27^{\circ} 47^{\prime} 34.51^{\prime \prime} \mathrm{S}, 50^{\circ} 20^{\prime} 44.44^{\prime \prime} \mathrm{W}\right)$ had native shallow forest on the left, exotic vegetation on the right, and standing water; the point $3\left(27^{\circ} 47^{\prime} 25.68^{\prime \prime} \mathrm{S}, 50^{\circ} 20^{\prime} 47.05^{\prime \prime} \mathrm{W}\right)$ contained a riparian forest gallery preserved, with native bamboo and rock bottom with little sediment; the point $4\left(27^{\circ} 47^{\prime} 26.30^{\prime \prime} \mathrm{S}\right.$, $50^{\circ} 20^{\prime} 46.86^{\prime \prime} \mathrm{W}$ ) had a preserved riparian forest with the presence of a waterfall with standing water; the point 5 $\left(27^{\circ} 47^{\prime} 26.75^{\prime \prime} \mathrm{S}, 50^{\circ} 20^{\prime} 46.28^{\prime \prime} \mathrm{W}\right)$ had a riparian forest with native preserved gallery vegetation; the point $6\left(27^{\circ} 47^{\prime} 30.83^{\prime \prime}\right.$ $\mathrm{S}, 50^{\circ} 20^{\prime} 41.98^{\prime \prime} \mathrm{W}$ ) was characterized by being the entry point for the trails, and had native vegetation along its banks; the point $7\left(27^{\circ} 47^{\prime} 28.44^{\prime \prime} \mathrm{S}, 50^{\circ} 20^{\prime} 39.83^{\prime \prime} \mathrm{W}\right)$ contained a wellpreserved riparian forest and rock bottom; and the point 8 $\left(27^{\circ} 47^{\prime} 20.96^{\prime \prime} \mathrm{S}, 50^{\circ} 20^{\prime} 24.57^{\prime \prime} \mathrm{W}\right)$, outside the park, also had a preserved riparian forest, but smaller in width and with houses in its vicinity.

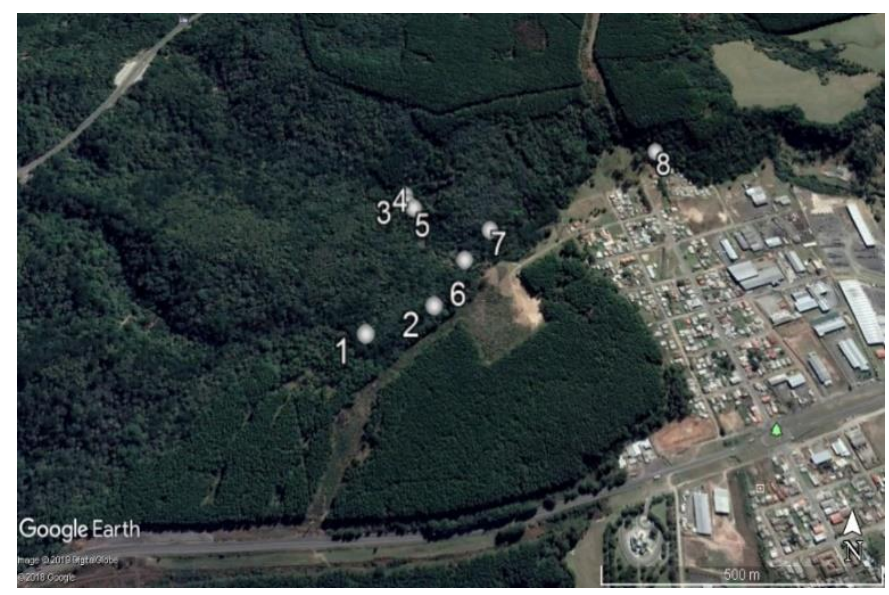

Figure 1. Distribution of collection points and surroundings of José Theodoro da Costa Neto Municipal Park, Lages, SC.

\section{Collection}

For the analysis of the parameters of the WQI and the benthic macroinvertebrate communities, two water and sediment collections were carried out, the first on June 7, 2018, and the second on August 13, 2018. The first collection was in the fall during the morning, with haze and cold, and the flow of the rivers was low due to a long period of drought that preceded that date. The second collection was in the winter during the afternoon, with sun and open sky, and the flow of the rivers was higher than the previous collection.

\section{WQI Parameters}

The water quality index (WQI) is an indicator that simultaneously analyzes nine physical-chemical and biological parameters considered important for the evaluation of water: water temperature, hydrogenation potential $(\mathrm{pH})$, dissolved oxygen (DO), biochemical oxygen demand (BOD), thermotolerant coliforms, total nitrogen, total phosphorus, total solids and turbidity (Agência Nacional de Águas, 2017). For a better accuracy of results, analyses of total phosphorus and total nitrogen were performed in duplicate because they are methodologies that are more complex. The rest of the parameters were obtained through a single sample. The parameters analyzed were also compared to the Conama Resolution no. 347 (Brazil, 2005) for the classification of points into quality classes.

The parameters dissolved oxygen and water temperature were measured in loco using a portable oximeter (DO-5519 
Cienlab). The parameters color and turbidity were measured using photometer equipment (Spectroquant NOVA 60a ). The hydrogen ion potential $(\mathrm{pH})$ of the samples was measured using a $\mathrm{pH}$ meter (LUCA-210).

For the identification of thermotolerant coliforms, the Aquatest Coli method, developed by the Laborclin laboratory (Laborclin, 2018), was applied after collecting the water samples in previously sterilized autoclave glass bottles conditioned on ice. In the laboratory, the reagent was added to each $100 \mathrm{~mL}$ of the sample, shaking it until the homogenization of the contents. Afterwards, it was divided into five bottles of $20 \mathrm{~mL}$ previously sterilized in $5 \%$ nitric acid. For the quantitative test, the bottles were placed for incubation in an oven at $35^{\circ} \mathrm{C}$ for 24 hours. Positive samples for coliforms could be detected visually by the development of a yellow color in the culture medium. In order to observe the presence of $E$. coli, the samples were subjected to the action of a portable light bulb (BioAmerica Inc.) emitting ultraviolet light (wavelength of $366 \mathrm{~nm}$ ). A greenish fluorescence indicated a positive proof.

The determination of biochemical oxygen demand was performed according to the procedures described in the Standard Methods for the Examination of Water and Waste Water (Rice, Baird \& Clesceri, 2017). A volume of $432 \mathrm{~mL}$ of sample was measured. Then, this volume was transferred to an amber bottle containing a magnetic stirrer. Two $\mathrm{NaOH}$ pellets were added to the rubber carrier of the bottle. The bottles containing the specimens from each point were identified and transferred to an OxiTop IS 12 inductive stirring system $\left(\mathrm{WTW}^{\circledR}{ }^{\circledR}\right.$, Germany), and kept incubated at a controlled temperature of $20^{\circ} \mathrm{C}$ for a period of five days. The $\mathrm{BOD}_{5}$ reading was made directly on the equipment display.

For the determination of the amount of total solids in the sample, the material in the muffle was calcined at $550^{\circ} \mathrm{C}$ for one hour. The samples were then placed in a desiccator until they reached room temperature, and were then identified and weighed on an analytical scale to determine dry weight. Using a measuring cylinder, $20 \mathrm{~mL}$ of each sample was placed in crucibles, which were placed immediately afterwards in an oven at $105^{\circ} \mathrm{C}$ for 24 hours. Afterwards, the crucibles were removed from the greenhouse and placed in a desiccator, and then weighed again using an analytical balance.

The methodology for the determination of total nitrogen was performed by the method of the American Public Health Association, available in the book Standard Methods for the Examination of Water and Wastewater. $2.5 \mathrm{~mL}$ of the sample were added in a test tube, followed by $650 \mu \mathrm{L}$ of $95-97 \%$ p.a. sulfuric acid and one spatula of the catalyst mix. This solution was taken to a digester coupled to a gas exhaust hood. It was set at $400^{\circ} \mathrm{C}$, and the sample was kept for 30 minutes at this temperature. After reaching room temperature, $6.5 \mathrm{~mL}$ of $40 \% \mathrm{NaOH}$ were added, and the sample was distilled in a nitrogen distiller $\left(\mathrm{Tecnal}^{\circledR}\right.$, Brazil). A receiver flask containing $2.5 \mathrm{~mL}$ of $2 \%$ boric acid solution was placed at the output of the distiller. After this step, the solution obtained at the output of the distiller was titrated with $0.01 \mathrm{M}$ hydrochloric acid until the color changed from green to red, marking the end of the titration. The concentration was calculated by the molar balance between the titrant and the titrated.
For the analytical determination of phosphorus, the methodology proposed by the Environmental Protection Agency in the book Methods for the Examination of Water and Waste water was used. To determine the phosphorus in the sample, $5 \mathrm{~mL}$ of the sample and $800 \mu \mathrm{L}$ of a combined reagent described by Rice et al. (2017) were added and then homogenized in vortex-type equipment. A period of ten minutes was allowed for ammonium molybdate and antimony/potassium tartrate to react in the acid medium containing orthophosphate and to form phosphomolybdic acid, which was subsequently reduced to molybdenum, which, by the action of ascorbic acid, developed a blue coloration. The concentration reading was performed using a Pharo 300 spectrophotometer (Merck, Germany) at a wavelength of 880 $\mathrm{nm}$ using a $50 \mathrm{~mm}$ cuvette. The result was divided by 20 , thus resulting in the concentration of phosphorus in the sample.

\section{Calculation of WQI}

The calculation of the WQI, according to the National Water Agency, was performed using the software QualiGraf 2018, taking into consideration the average of the parameters between collections.

The index is composed of nine parameters with their respective weights (w), which were fixed according to their importance for the overall conformation of water quality (Agência Nacional das Águas, 2017): dissolved oxygen (w = $0.17)$, thermotolerant coliforms $(\mathrm{w}=0.15)$, hydrogen ion potential $(\mathrm{w}=0.12)$, biochemical oxygen demand $\left(\mathrm{BOD}_{5}\right)(\mathrm{w}$ $=0.10)$, temperature $(\mathrm{w}=0.10)$, total nitrogen $(\mathrm{w}=0.10)$, total phosphorus $(\mathrm{w}=0.10)$, turbidity $(\mathrm{w}=0.08)$, and total residues $(\mathrm{w}=0.08)($ ANA, 2005).

In addition to weight (w), each parameter has a quality value (q) obtained from the respective quality chart in function of its concentration or measurement (ANA, 2005). The calculation of the WQI is performed by weighting the nine parameters according to the Equation below.

$$
I Q A=\prod_{i=1}^{n} q i^{w i}
$$

Where:

$\mathrm{WQI}=$ water quality index; qi $=$ quality of the $\mathrm{i}$-th parameter; $\mathrm{n}=$ number of parameters that comprise the WQI calculation; wi $=$ weight corresponding to the $\mathrm{i}$-th parameter set according to its importance.

The global conformation of quality is a number between 0 and 1 . The sum of wi should be equal to 1 (Equation below).

$$
\sum_{i=1}^{n} w i=1
$$

For the qualification of the WQI, it was observed in which category the value was according to Table 1.

\section{Benthic macroinvertebrates}

In order to evaluate the water quality using biological indexes, sediments were collected at each point containing benthic macroinvertebrates on the left and right bank and at the bottom of the river using a Surber sampler. 
Table 1. Value of the water quality index (WQI) and its respective category.

\begin{tabular}{cc}
\hline $\mathrm{WQI}$ & Category \\
\hline $79<\mathrm{WQI} \leq 100$ & Optimal \\
$51<\mathrm{WQI} \leq 79$ & Good \\
$36<\mathrm{WQI} \leq 51$ & Regular \\
$19<\mathrm{WQI} \leq 36$ & Poor \\
$\mathrm{WQI} \leq 19$ & Very poor \\
\hline
\end{tabular}

Source: CETESB (2015).

The collected material was stored in previously identified plastic bags and transported to the Laboratory of Environmental Toxicology of the Department of Environmental and Sanitary Engineering of UDESC. In the laboratory, the bags were kept refrigerated while the macroinvertebrates were separated from the pellet, which were stored in glass jars containing 70\% alcohol after screening. After the screening, the identification stage began. The individuals were counted and identified up to the family level, whenever possible, and stored in $70 \%$ alcohol in labeled acrylic jars.

The richness of taxa and the abundance of individuals were counted, as well as the indexes Shannon Diversity, Equity $\mathrm{J}$ and Dominance D. The parameters were calculated using the software Past 2.1 (Hammer, Harper \& Ryan, 2001).

\section{Calculation of the $B M W P^{\prime}$ index}

For the application of the BMWP' index, the degree of sensitivity of organisms to pollution is taken into account. The most sensitive organisms receive the highest scores. After the identification of the organisms, the BMWP' index was applied. Each point was qualified according to the sum of the families found taking into account their respective weight (SEMA/PR, 2018). According to Alba-Tercedor \& Sánchez-Ortega (1988), the classification of water according to the value attributed by the BMWP' index, with modifications of SEMA/PR (2018), is presented in Table 2.

Table 2. Water quality classification and meaning of the BMWP' index values.

\begin{tabular}{ccl}
\hline Class & Value & \multicolumn{1}{c}{ Meaning } \\
\hline I & $>150$ & $\begin{array}{l}\text { Very clean waters (pristine waters); } \\
\text { Clean, non-polluted water or } \\
\text { perceptibly unchanged system; } \\
\text { II }\end{array}$ 121-150 \\
III & $101-120$ & $\begin{array}{l}\text { Very little polluted water, or system } \\
\text { already with small changes; } \\
\text { Moderate pollution effects are evident; } \\
\text { Contaminated or polluted water } \\
\text { (changed system); Very polluted waters } \\
\text { (much changed system); Heavily } \\
\text { polluted waters (heavily changed } \\
\text { system) }\end{array}$ \\
\hline
\end{tabular}

\section{Results and Discussion}

The results for chemical, physical and microbiological parameters evaluated are shown in Table 3.
The dissolved oxygen and the temperature of the water were correlated. There is a decrease in the dissolved oxygen as temperature increases. The volume of oxygen in the water under normal conditions depends on the temperature, the amount of salts and the atmospheric pressure, therefore a cooler water retains more oxygen (Embrapa, 2019). This relation was observed in results obtained between collections: in the first collection, the temperature was lower, and consequently the dissolved oxygen was higher. On the other hand, in the second collection, where the temperature was higher, the dissolved oxygen was low.

About $40 \%$ of the sites presented low DO values in both collections. According to the CONAMA Resolution no. 357, they are in classes II and III. Low dissolved oxygen values affect the maintenance of life of aerobic organisms in the aquatic environment, contributing to a population increase of tolerant groups such as Chironomidae and Oligochaeta (Barbola et al., 2011). The other sites evaluated were classified as class $\mathrm{I}$.

In both collections, all coliforms had total coliforms for Escherichia coli. Most of them were greater than 8.0 NMP/100 $\mathrm{mL}$ of sample, which does not necessarily indicate that the contamination is by sewage; it can be by the park's own warmblooded animals. Silva \& Sá-Oliveira (2014), evaluating the integrity of the rivers of a Natural Heritage Particular Reserve (NRPR) in Amapá, also found values of coliforms higher than expected for a natural reserve area.

According to Matthiensen (2014b), the total coliform group comprises all thermotolerant coliforms, fecal bacteria and some bacteria that can be isolated from the environment. Therefore, for the author, the presence of total coliforms in a sample may or may not indicate fecal contamination. Even massive concentrations of total coliforms do not necessarily indicate the presence of fecal bacteria, which may originate from the transport of organic matter from the soil to the water.

By the CONAMA Resolution no. 357, all points were classified by $\mathrm{BOD}_{5}$ into class I (BOD $=0 \mathrm{mg} \mathrm{L}^{-1}$ ), except for the point 7 , which was classified into class III in the first collection $\left(\mathrm{BOD}=9 \mathrm{mg} \mathrm{L}^{-1}\right)$. This site had a stagnant water area with a great concentration of accumulated organic matter. According to Silva \& Sá-Oliveira (2014), this means a high concentration of aerobic organisms consuming oxygen to degrade debris.

The values obtained for total solids and total nitrogen in the points fall into the class I of the CONAMA Resolution no. 357. Similar to this study, Silva \& Sá-Oliveira (2014) found low values for total solids of rivers in a reserve area in Amapá, which may indicate a low input of organic matter into the environment, both of natural origin and anthropogenic origin.

The phosphorus concentration fit all points in class I, with the exception of the points 1,2 and 8, which presented higher values. Phosphorus is the main limiting factor of the primary productivity of aquatic ecosystems. It is an important factor responsible for artificial eutrophication (Souza, Moraes, Sonoda \& Santos, 2014). Its concentration in some points shows a drag of possible contaminants since, in general, its concentrations in natural aquatic environments are low as long as there is no related anthropogenic source (Esteves, 2011). 
Table 3. Values determined for the physical-chemical parameters analyzed in the streams inside the José Theodoro da Costa Neto Municipal Park, Lages, SC.

\begin{tabular}{|c|c|c|c|c|c|c|c|c|}
\hline \multirow[b]{2}{*}{ Site } & \multicolumn{7}{|c|}{ Collection 1} & \multirow[b]{2}{*}{$\mathrm{pH}$} \\
\hline & $\begin{array}{l}\text { Dissolved } \\
\text { oxygen } \\
\left(\mathrm{mg} \mathrm{L}^{-1}\right)\end{array}$ & $\begin{array}{c}\text { Temperature } \\
\left({ }^{\circ} \mathrm{C}\right)\end{array}$ & $\begin{array}{c}\text { Escherichia } \\
\text { coli } \\
\text { NMP/100 mL } \\
\text { of sample }\end{array}$ & $\begin{array}{l}\text { Color } \\
\left(\mathrm{mg} \mathrm{L}^{-1}\right)\end{array}$ & $\begin{array}{l}\text { Turbidity } \\
\text { (NTU) }\end{array}$ & $\begin{array}{c}\text { Total } \\
\text { solids } \\
\left(\mathrm{mg} \mathrm{L}^{-1}\right)\end{array}$ & $\begin{array}{l}\text { Phosphorus } \\
\left(\mathrm{mg} \mathrm{L}^{-1}\right)\end{array}$ & \\
\hline 1 & 7.7 & 8.2 & $>8.0$ & 44.9 & 12 & 0.02 & 0.109 & 7.0 \\
\hline 2 & 7.1 & 9.6 & $>8.0$ & 40.8 & 11 & - & 0.123 & 7.0 \\
\hline 3 & 9.2 & 8.7 & $>8.0$ & 19.4 & 4 & - & - & 7.1 \\
\hline 4 & 8.9 & 8.3 & $>8.0$ & 19.5 & 4 & 0.01 & - & 7.2 \\
\hline 5 & 9.2 & 8.5 & $>8.0$ & 18.6 & 3 & 0.01 & 0.03 & 7.2 \\
\hline 6 & 7.9 & 8.5 & $>8.0$ & 39.6 & 10 & 0.01 & 0.08 & 6.9 \\
\hline 7 & 8.5 & 8.5 & $>8.0$ & 34.3 & 9 & 0.01 & 0.067 & 7.0 \\
\hline 8 & 8.9 & 8.7 & $>8.0$ & 59.7 & 21 & - & 0.152 & 6.9 \\
\hline \multicolumn{9}{|c|}{ Collection 2} \\
\hline Site & $\begin{array}{l}\text { Dissolved } \\
\text { oxygen } \\
\left(\mathrm{mg} \mathrm{L}^{-1}\right)\end{array}$ & $\begin{array}{c}\text { Temperature } \\
\left({ }^{\circ} \mathrm{C}\right)\end{array}$ & $\begin{array}{c}\text { Escherichia } \\
\text { coli } \\
\text { NMP/100 mL } \\
\text { of sample }\end{array}$ & $\begin{array}{l}\text { Color } \\
\left(\mathrm{mg} \mathrm{L}^{-1}\right)\end{array}$ & $\begin{array}{l}\text { Turbidity } \\
\text { (NTU) }\end{array}$ & $\begin{array}{c}\text { Total } \\
\text { solids } \\
\left(\mathrm{mg} \mathrm{L}^{-1}\right)\end{array}$ & $\begin{array}{l}\text { Phosphorus } \\
\left(\mathrm{mg} \mathrm{L}^{-1}\right)\end{array}$ & \\
\hline 1 & 5.3 & 14.3 & 8.0 & 34.9 & 7 & 0.005 & 0.085 & \\
\hline 2 & 4.6 & 15.4 & 8.0 & 34.0 & 7 & 0.001 & 0.076 & \\
\hline 3 & 6.0 & 15.8 & 4.6 & 16.6 & 5 & - & - & \\
\hline 4 & 6.3 & 16.0 & 8.0 & 12.5 & 3 & - & - & \\
\hline 5 & 6.2 & 17.3 & $>8.0$ & 12.3 & 4 & - & - & \\
\hline 6 & 5.0 & 16.0 & $>8.0$ & 33.9 & 6 & - & 0.058 & \\
\hline 7 & 8.0 & 15.5 & $>8.0$ & 104 & 31 & - & 0.063 & \\
\hline 8 & 7.6 & 12.5 & 8.0 & 38.2 & 16 & - & 0.032 & \\
\hline
\end{tabular}

*Values not shown in the Table were lower than the reading capability of the equipment.

According to the CONAMA Resolution no. 357, all points were within the class I for $\mathrm{pH}$ and turbidity. There was a significant difference between the turbidity from the first to the second collection. The first collection presented higher values that can be attributed to an intense rainfall occurring before this first collection, as it was preceded, as already mentioned, by a drought period. Matthiensen (2014b) notes that, after an extreme condition, such as heavy rainfalls, a river usually carries a higher load of suspended material, and consequently will have greater turbidity.

For biological analyses, 4,274 benthic macroinvertebrate individuals were identified in 31 taxa (Table 4).

In the first collection, 1,335 benthic macroinvertebrates belonging to 24 taxa were identified. In the second collection, in turn, 2,939 individuals were identified in 23 taxa. Barbola et al (2011) reported an increase in taxonomic density of most groups during the rainy season. The same effect was observed in the present study: in the second collection, there was a significant increase in the number of individuals. This can be justified because, by increasing the river flow, there is a greater loading of allochthone material from the littoral and sublittoral area to its bed, thus increasing the number of habitats for benthic macroinvertebrates (Callisto 2001; Barbola et al, 2011).

By analyzing the individuals found at all points (Table 4), there is a dominance of Oligochaeta and Chironomidae, both resistant to pollution. Undisturbed environments are characterized by a high taxonomic diversity and a homogeneous distribution of individuals among species. Disturbed environments present a decrease in diversity and an increase in the dominance of tolerant species (Amorin \& Castillo, 2009; Copatti, Schirmer \& Machado, 2010; Taniwacki \& Smith 2011). Based on this, the evaluated points have different levels of disturbance.

The points 3, 4 and 5 presented the greatest taxonomic richness, diversity and equitability. The dominance was higher for the points 1,2, 6 and 8 due to the high abundance of Oligochaeta and Chironomidae collected at these sites (Table 5).

Silva, Everton \& Melo (2016) have associated the increase of turbidity with the decrease of diversity. In the present work, this relationship is visible, and the Shannon index presented higher values at the points where the turbidity presented lower values. Such high turbidity is associated with a greater sediment input into the ecosystem, which leads to an increase in debris that will serve as food for Oligochaeta and Chironomidae.

For the application of the BMWP' biological index, the sum of both collections was taken into account. Based on Table 2, the points fit their classes, resulting in scores and the classification shown in Table 5. 
By analyzing the results obtained by the BMWP' index, the points 3, 4 and 5 obtained the best quality among the evaluated points. The water was very little polluted, and there was some change in the ecosystem, but little significant. The points 1, 6 and 7 showed moderate pollution effects. In turn, the points 2 and 8 presented the worst results, with contaminated or polluted waters.

The WQI results for each point and their respective classification, according to Table 1 , are expressed in Table 5.

As for the BMWP' index, the points 3, 4 and 5 obtained the best score, indicating that the streams at these points are better preserved among the points evaluated in this study. The points 1, 6 and 8 were also classified with an optimal quality, and the other points with a good water quality.

The points 1 and 2, belonging to the same quality results, had similar characteristics. Both presented characteristics of changed environments, where quality was worse than expected because they were inside the park. The point 1 had a better quality than point 2 . The two main characteristics that explain this result are the quota (the point 2 was at the lower quota, more favorable to the input of contaminants from the surroundings of the park), and the riparian forest (the point 1 presented a preserved native forest, while point 2 is on one of the banks with exotic vegetation and erosion points with evident input of allochthone sediment).

Table 4. Total benthic macroinvertebrates identified at the eight collection points in the streams inside the José Theodoro da Costa Neto Municipal Park, Lages, SC.

\begin{tabular}{|c|c|c|c|c|c|c|c|c|}
\hline Taxon/Points & Point 1 & Point 2 & Point 3 & Point 4 & Point 5 & Point 6 & Point 7 & Point 8 \\
\hline Acari & 1 & 1 & 19 & 102 & 10 & 1 & 0 & 1 \\
\hline Aeglidae & 1 & 1 & 3 & 3 & 22 & 15 & 4 & 5 \\
\hline Aeshnidae & 0 & 0 & 0 & 1 & 3 & 0 & 0 & 0 \\
\hline Baetidae & 0 & 0 & 13 & 83 & 0 & 1 & 1 & 1 \\
\hline Caenidae & 0 & 0 & 2 & 6 & 2 & 13 & 0 & 0 \\
\hline Ceratopogonidae & 0 & 1 & 2 & 0 & 2 & 0 & 1 & 0 \\
\hline Chironomidae & 792 & 8 & 29 & 193 & 123 & 77 & 10 & 57 \\
\hline Coenagrionidae & 0 & 0 & 1 & 0 & 1 & 0 & 1 & 0 \\
\hline Collembola & 0 & 0 & 2 & 0 & 6 & 0 & 0 & 0 \\
\hline Culicidae & 1 & 0 & 0 & 6 & 0 & 0 & 0 & 0 \\
\hline Dixidae & 0 & 0 & 0 & 2 & 1 & 0 & 0 & 0 \\
\hline Elmidae & 0 & 0 & 1 & 0 & 1 & 3 & 2 & 0 \\
\hline Empididae & 0 & 0 & 1 & 0 & 0 & 0 & 0 & 0 \\
\hline Gripopterygidae & 0 & 0 & 1 & 1 & 0 & 0 & 0 & 0 \\
\hline Helicopsychidae & 1 & 0 & 0 & 0 & 8 & 0 & 0 & 0 \\
\hline Hirudinida & 9 & 0 & 0 & 0 & 0 & 0 & 0 & 0 \\
\hline Hyalellidae & 0 & 0 & 0 & 0 & 0 & 0 & 1 & 0 \\
\hline Hydrobiidae & 0 & 0 & 2 & 0 & 63 & 2 & 1 & 0 \\
\hline Leptoceridae & 2 & 0 & 11 & 2 & 27 & 9 & 0 & 0 \\
\hline Leptophlebiidae & 0 & 0 & 14 & 50 & 8 & 55 & 0 & 0 \\
\hline Libellulidae & 0 & 0 & 0 & 0 & 2 & 0 & 0 & 1 \\
\hline Oligochaeta & 200 & 835 & 12 & 195 & 2 & 989 & 39 & 43 \\
\hline Polycentropodidae & 0 & 0 & 0 & 0 & 0 & 1 & 0 & 0 \\
\hline Psephenidae & 0 & 0 & 4 & 0 & 1 & 0 & 0 & 0 \\
\hline Psocoptera & 0 & 0 & 0 & 0 & 0 & 0 & 7 & 0 \\
\hline Pyralidae & 0 & 1 & 0 & 0 & 0 & 0 & 0 & 0 \\
\hline Scirtidae & 0 & 0 & 0 & 1 & 0 & 0 & 0 & 0 \\
\hline Stratiomyidae & 0 & 1 & 0 & 0 & 0 & 0 & 0 & 0 \\
\hline Tabanidae & 0 & 0 & 0 & 1 & 0 & 0 & 0 & 0 \\
\hline Tipulidae & 0 & 4 & 4 & 4 & 18 & 1 & 1 & 0 \\
\hline Torridincolidae & 0 & 0 & 0 & 1 & 0 & 0 & 0 & 0 \\
\hline Total & 1,007 & 852 & 121 & 651 & 300 & 1,167 & 68 & 108 \\
\hline
\end{tabular}


Pollhein et al. - Characterization of surface water

Table 5. Indexes applied to benthic macroinvertebrate taxa collected in the streams inside the José Theodoro da Costa Neto Municipal Park, Lages, SC.

\begin{tabular}{|c|c|c|c|c|c|c|c|c|}
\hline Point & & & & Fauna & ndexes & & & \\
\hline Total richness & 8 & 8 & 17 & 16 & 18 & 12 & 11 & 6 \\
\hline Total abundance & 1,007 & 852 & 121 & 651 & 300 & 1,167 & 68 & 108 \\
\hline Dominance & 0.66 & 0.96 & 0.13 & 0.22 & 0.23 & 0.72 & 0.37 & 0.44 \\
\hline Shannon Index & 0.59 & 0.13 & 2.32 & 1.7 & 1.91 & 0.66 & 1.48 & 0.98 \\
\hline Equitability & 0.29 & 0.06 & 0.82 & 0.6 & 0.66 & 0.26 & 0.62 & 0.54 \\
\hline \multicolumn{9}{|c|}{ BMWP' index } \\
\hline Value & 37 & 32 & 81 & 70 & 96 & 60 & 41 & 24 \\
\hline Classification & IV & $\mathrm{V}$ & III & III & III & IV & IV & $\mathrm{V}$ \\
\hline \multicolumn{9}{|c|}{ WQI index } \\
\hline $\begin{array}{l}\text { Value } \\
\text { Classification }\end{array}$ & $\begin{array}{c}81 \\
\text { Optimal }\end{array}$ & $\begin{array}{c}79 \\
\text { Good }\end{array}$ & $\begin{array}{c}88 \\
\text { Optimal }\end{array}$ & $\begin{array}{c}87 \\
\text { Optimal }\end{array}$ & $\begin{array}{c}87 \\
\text { Optimal }\end{array}$ & $\begin{array}{c}81 \\
\text { Optimal }\end{array}$ & $\begin{array}{c}79 \\
\text { Good }\end{array}$ & $\begin{array}{c}83 \\
\text { Optimal }\end{array}$ \\
\hline
\end{tabular}

Although the WQI classifies the point 2 as having a good water quality, the lowest value of dissolved oxygen was obtained at this point among other analyzed river sections. Pereira-Silva et al. (2011) observed that the absence of riparian forests on one of the riverbanks allows a higher incidence of solar radiation, increasing water temperature and decreasing dissolved oxygen concentration. It can also be highlighted that this site presented the lowest BMWP' index value for the points within the park and the highest values of dominance, with a low diversity index.

Based on the values obtained for the BMWP' index and ecological indexes, such as the Shannon index, the points 3, 4 and 5 presented the best results. Observing the taxa found at these sites, there is a greater richness in both collections for these points. Some taxa are sensitive to pollution, such as the Aeshnidae and Leptoceridae families.

This finding can be justified by some factors. These points belong to the same stream, and are further away from the industries and buildings around the park, which does not favor the transport of pollutants to the interior of the park. All three points have with well-preserved native riparian forest, which provides food and shelter to the aquatic biota. In addition, this region provides the maintenance of temperature and humidity conditions and a reduction of pollutants and sediment input into the main channel of the river.

According to the WQI, these points also presented very similar results, with an optimum quality of water. Low values of turbidity and phosphorus were also observed between the studied points.

In relation to the values obtained for the WQI, the points 6 and 7 were classified with optimal and good quality, respectively. The parameters that influenced the point 7 to result in a quality lower than the point 6 were the highest BOD and turbidity, although the dissolved oxygen at this point had a high value. The transport of suspended solids and the consequent increase in turbidity are generally associated with rainfalls and water runoff conditions (Agência Nacional de Águas, 2017).

Based on the BMWP' index, both sites showed moderate signs of pollution. By observing the location of these points, it is known that the point 6 is at the beginning of the park trail and the point 7 is further away, both of which belong to the same stream. This stream is formed by the meeting of the slopes of points 1 and 2 with the slopes of points 3, 4 and 5, 46 receiving, in this way, water from several points of the park.

Both points had a similar richness, but the point 7 had a higher Shannon Diversity index. The abundance at the site was low probably due to an abiotic factor that limited the occurrence of organisms and that was responsible for increasing the Shannon Diversity index, matching the site to points with better water quality. By analyzing Table 5, the greatest abundance was of Oligochaeta, organisms tolerant to high concentrations of organic matter in the sediment.

Although the point 8 was scored according to the WQI with an optimum quality, the BMWP' index indicated polluted or polluted waters. This difference between index results can be attributed to the greater sensitivity of the BMWP' and the lack of parameters considered for the WQI, which are also indicative of pollution.

This point is located outside the park, and is possibly subject to dump or pollutant loading into the stream of houses around it. By observing the benthic macroinvertebrate communities of this point, there is a low diversity of families and the dominance of more resistant individuals.

The results of the WQI indicated a better water quality than the BMWP' results. This may be due to the greater sensitivity of the BMWP' index to water contamination, and the need to introduce biological analysis into water monitoring systems.

The oscillations of the WQI variables compensate for each other, keeping the index at a relatively stable level. However, this relative "stability" masks important fluctuations in the environment, which should be monitored and analyzed more carefully so that any problems can be corrected (Piasentin, et al., 2009).

For Viana et al. (2013), the evaluation of water using only the WQI presents limitations. It does not analyze other important parameters such as toxic substances (heavy metals, pesticides, and organic compounds), pathogenic protozoa, and substances that may interfere with the main organoleptic properties of water.

The BMWP' index has proven to be consistent compared to biodiversity indexes. It is important to note, however, that the BMWP' index does not take into account the number of individuals in a taxon, but only its presence. In this context, indexes such as Shannon are complementary and may contribute to more accurate results of water quality by considering faunal biodiversity. 
The joint use of indexes allows a better understanding of the characteristics of each point as well as a better diagnosis of water quality. In addition, the parameters should also be analyzed in isolation. They can be used as a basis for legislation, such as the Resolution no. 357 of 2005 (CONAMA, 2010).

\section{Conclusions}

The water resources of the Municipal Natural Park have been contaminated. The BMWP' index is more sensitive to the presence of pollutants than the WQI, although both present values that group some streams into similar quality levels. The points closer to the edges of the park show a significant difference in water quality, emphasizing the need for a systemic view that also covers the surroundings of the conservation unit in order to verify possible sources of pollution that are changing it. In this respect, it is important to consider in future works characteristics such as the presence of riparian forests and the quota of the evaluated areas, as well as the importance of buffer zones for conservation units.

\section{References}

Alba-Tercedor, J., \& Sánchez-Ortega, A. (1988). Un Método Rápido Y Simple Para Evaluar la Calidad Biológica de las Aguas Corrientes Basado en el de Hellawell (1978). Limnetica, 4, 51-56. https://www.limnetica.com/documentos/limnetica/limnetica-4-1-p51.pdf

Agência Nacional de Águas (Ana) (2017). Conjuntura: Recursos Hídricos. Brasília, Brasil. Recuperado de http://www.snirh.gov.br/portal/snirh/centrais-de-conteudos/conjunturados-recursos-hidricos

Agência Nacional das Águas (2018). Indicadores de qualidade: Índice de qualidade da água (IQA). Recuperado de http://www3.ana.gov.br/portal/ANA/panorama-das-aguas/qualidadeda-agua/indicadores-de-qualidade

American Amorim, A.C.F., \& Castillo, A.R. (2009). Macroinvertebrados bentônicos como bioindicadores da qualidade da água do baixo rio perequê, Cubatão, São Paulo, Brasil. Biodiversidade Pampeana, 7(1), $16-22$.

http://revistaseletronicas.pucrs.br/ojs/index.php/biodiversidadepampea na/article/viewFile/5454/5036

Amorim, A. C. F., \& Castillo, A. R. (2009). Macroinvertebrados bentônicos como bioindicadores da qualidade da água do baixo rio Perequê, Cubatão, São Paulo, Brasil. Biodiversidade Pampeana, 7 (1), 16-22. http://revistaseletronicas.pucrs.br/ojs/index.php/biodiversidadepampea na/article/viewFile/5454/5036

Brasil (2005). Resolução Conama no 357, de 17 de março de 2005. Brasília, 58-63. Recuperado de http://www.mma.gov.br/port/conama/legiabre.cfm?codlegi=459

Barbola, I.F., Moraes, M.F. P.G., Anazawa, T.M. Nascimento, E.A., Sepka, E.R., Polegatto, C.M., Milléo, J., \& Schühli, G.S. (2011). Avaliação da comunidade de macroinvertebrados aquáticos como ferramenta para o monitoramento de um reservatório na bacia do rio Pitangui, Paraná, Brasil. Iheringia, Série Zoologia, 101(1-2), 15-23. http://www.scielo.br/pdf/isz/v101n1-2/v101n1-2a02.pdf

Callisto, M., Moretti, M., \& Goulart, M.D.C. (2010). Macroinvertebrados bentônicos como ferramenta para avaliar a saúde de riachos. Revista Brasileira de Recursos Hídricos, 6(1), 71-82. http://labs.icb.ufmg.br/benthos/index_arquivos/pdfs_pagina/callisto.et. al.2001.RBRH.pdf

Cetesb (2015). Qualidade das Águas Superficiais do Estado de São Paulo. São Paulo: Cetesb. Recuperado de https://www.cetesb.sp.gov.br/wpcontent/uploads/sites/12/2013/11/Cetesb_QualidadeAguasSuperficiais2 014_ParteI_vers\%C3\%A3o2015_Web.pdf

Copatti, CE., Schirmer, FG., \& Machado, J.V.V. (2010). Diversidade de macroinvertebrados bentônicos na avaliação da qualidade ambiental de uma microbacia no sul do Brasil. Perspectiva, 34 (125), 79-91. http://www.scielo.br/scielo.php?script=sci_nlinks\&ref=000083\&pid=S2 179-975X201400020000300013\&lng=en

Embrapa (2019). Oxigênio dissolvido. Recuperado de https://www.embrapa.br/meio-ambiente

Eesteves, F.A. (2001). Fundamentos de Limnologia. (3a ed.) Rio de Janeiro: Interciência.

Hammer, Ø., Harper, D.A.T., \& Ryan, P.D. (2001). PAST: Paleontological Statistics Software Package for Education and Data Analysis. Palaeontology Electronic, $\quad 4, \quad 1-9 . \quad$ https://palaeoelectronica.org/2001_1/past/past.pdf

Maane-Messai, S., Laignel, B., Motelay-Massei, A., Madani, K., \& Chibane, M. (2010). Spatial and temporal variability of water quality of an urbanized river in Algeria: The case of Soummam Wadi. Water Environment Research, 82(8). https://doi.org/10.2175/106143009X12465435982854

Matthiensen, A. (2014). Introdução. In: Belli Filho, P. [Org.], Programa de capacitação em gestão da água: monitoramento e diagnóstico de qualidade de água superficial (1a ed., Cap. 1, pp 11-16) .Florianópolis: UFSC/DESA. Recuperado https://repositorio.ufsc.br/bitstream/handle/123456789/126567/Monitora mento\%20e\%20Diagn\%C3\%B3stico\%20de\%20Qualidade\%20de\%20\% C3\% 81 gua $\% 20$ Superficial $\% 20 \% 28 \mathrm{web} \% 29$.pdf?sequence=1\&isAllowe $\mathrm{d}=\mathrm{y}$

Matthiensen, A. (2014b). Parâmetros microbiológicos da água. In: Belli Filho, P. [Org.], Programa de capacitação em gestão da água: monitoramento e diagnóstico de qualidade de água superficial (1a ed., Cap. 1, pp 11-16) .Florianópolis: UFSC/DESA. Recuperado de https://repositorio.ufsc.br/bitstream/handle/123456789/126567/Monitora mento\%20e\%20Diagn\%C3\%B3stico\%20de\%20Qualidade\%20de\%20\% C3\%81 gua\%20Superficial\%20\%28web\%29.pdf?sequence=1\&isAllowe $\mathrm{d}=\mathrm{y}$

Pereira-Silva, E.F.L., Hardt, E., Santos, J.E., Pires, J.S.R., \& Ferreira, W.A. (2011). Avaliação da qualidade da água em microbacias hidrográficas de uma Unidade de Conservação do Nordeste do estado de São Paulo, Brasil. Brazilian Journal of Biosciences, 9(3), 371-381. http://www.scielo.br/scielo.php?script=sci_nlinks\&ref=000149\&pid=S2 179-975X201300040000900052\&lng=en

Piasentin, A.M., Semensatto Junior, D.L., Saad, A.R., Monteiro Junior, A.J., \& Raczka, M.F. (2009). Índice de Qualidade da Água (IQA) do Reservatório Tanque Grande, Guarulhos (SP): Análise Sazonal e Efeitos do Uso e Ocupação do Solo. Geociências, 28(3), 305-317. https://www.revistageociencias.com.br/geocienciasarquivos/28_3/Art\%207_Piasentin.pdf

Prefeitura Municipal de Lages (2006). Plano de Manejo Participativo Parque Natural Municipal João José Theodoro da Costa Neto. Lages: Prosul. 218.

Rice, E.W., Baird, R.B., \& Clesceri, A.D. (2017). Standard Methods. (23a ed.). American Public Health: Pharmabooks.

Secretaria de Meio Ambiente e Recursos Hídricos - SEMA/PR (2018). Secretaria de Meio Ambiente e Recursos Hídricos. Recuperado de http://www.meioambiente.pr.gov.br/modules/conteudo/conteudo.php?co nteudo $=91$

Silva, E.S., \& Sá de Oliveira, J.C. (2014). Avaliação da qualidade da água da Reserva Particular do Patrimônio Natural (RPPN) Seringal Triunfo, Rio Araguari, Ferreira Gomes-AP-Brasil. Biota Amazônia, 4(2), 28-42. doi: http://dx.doi.org/10.18561/2179-5746/biotaamazonia.v4n2p28-42

Silva, K.W.S., Everton, N.S., \& Melo, M.A.D. (2016). Aplicação dos índices biológicos Biological Monitoring Working Party e Average Score per Taxon para avaliar a qualidade de água do rio Ouricuri no Município de Capanema, Estado do Pará, Brasil. Revista Pan-amazônica de Saúde, 7(3), 13-22. doi: http://dx.doi.org/10.5123/S2176-62232016000300002

Souza, J. R., Moraes, M.E.B., Sonoda, S.L., \& Santos, H.C.R.G. (2014). A Importância da Qualidade da Água e os seus Múltiplos Usos: Caso do Rio Almada, Sul da Bahia, Brasil. Rede: Revista Eletrônica do Prodema, 8, 26-45. http://www.periodicos.ufc.br/rede/article/view/1115

Taniwaki, R.H., \& Smith, W.S. (2011). Utilização de macroinvertebrados bentônicos no biomonitoramento de atividades antrópicas na bacia de drenagem do Reservatório de Itupararanga, Votorantim - SP, Brasil. Journal Health Science Institute, 29(1),7-10. https://www.researchgate.net/publication/220191277_Utilizacao_de_ma 
Pollhein et al. - Characterization of surface water

croinvertebrados_bentonicos_no_biomonitoramento_de_atividades_ant ropicas_na_bacia_de_drenagem_do_reservatorio_de_Itupararanga_SP _Brasil

Ramos, Viana, L.G., Dias, D.F.S., \& Oliveira, V.P.S. (2013). Wate rQuality Index (WQI) of the Lagoa do Taí, São João da Barra, RJ. Boletim do Observatório Ambiental Alberto Ribeiro Lamego, 7, 119-219.

\section{License: Creative Commons CC BY 4.0}

This article was published with open access for distribution under the terms of the Creative Commons Attribution License, which allows unrestricted use, distribution, and reproduction in any medium, provided the original work is properly cited. 